\title{
BACKGROUND AND ORIGINS OF PROFESSIONAL TRAINING OF PHYSICAL EDUCATION AND SPORTS TEACHERS IN AUSTRIA
}

\section{[ПРЕДПОСЫЛКИ СТАНОВЛЕНИЯ И ИСТОКИ СИСТЕМЫ ПРОФЕСИОНАЛЬНОЙ ПОДГОТОВКИ СПЕЦИАЛИСТОВ ПО ФИЗИЧЕСКОМУ ВОСПИТАНИЮ И СПОРТУ В АВСТРИИ]}

\author{
Olha Romanchuk
}

doi: 10.18355/PG.2019.8.1.1

\begin{abstract}
The article is devoted to the consideration of the development of the system of professional training of specialists in the field of physical education in Austria. It describes the main factors the system has been influenced by. The most important of them were political, economic, cultural, medical and biological ones. It has been defined origins and tendencies of the historical development of professional training of physical education and sports teachers in Austria. The papers of outstanding scientists in the field of education have been analyzed.
\end{abstract}

Key words

teachers training, physical education, sports, origins, Austria

\begin{abstract}
Аннотация
Статья посвящена изучению развития системы подготовки учителей по физическому воспитанию и спорту в Австрии. Представлены факторы, которые имели влияние на развитие системы, главные среди них политические, экономические, культурные, медицинские и биологические. Определены истоки и направления системы подготовки учителей по физическому воспитанию и спорту в историческом ракурсе. Проанализированы труды известных педагогов того времени.
\end{abstract}

\section{Ключевые слова}

подготовка учителей, физическое воспитание, спорт, зарождение, Австрия

\section{Вступление}

Современный этап развития украинского общества, стремительная динамика социально-экономического, политического, культурнодуховного развития государства предъявляют высокие требования к специалистам различных направлений, требует существенных изменений в системе профессионального образования. Особенно ощутимы потребности совершенствования профессиональной подготовки педагогических кадров, в том числе будущих учителей физического воспитания и спорта. 
Формирование и развитие национальной системы физического воспитания, переход к более эффективным формам физкультурнооздоровительной и спортивной работы с детьми и молодежью предопределяет необходимость обновления содержания и поиска эффективных форм, средств и методов подготовки учительских кадров в сфере физической культуры и спорта. Залогом успешного разработки и теоретического обоснования системы профессиональной подготовки специалистов по физической культуре и спорту на современном этапе развития украинского общества является исследование предпосылок и достижений как украинской высшей школы в целом, так и изучение опыта других стран, в частности.

Проблемы профессиональной подготовки специалистов по физическому воспитанию в Австрии является объектом пристального внимания ученых (G. Heintel, 2000; G. Grohl, 1962; K. Kleiner, 2001; R. Mülner, 2011; G. Stromayer, 1971; G. Shtromaer, 1992 and others) которые исследовали особенности ее реформирования и функционирования в исторической ретроспективе и условиях современности.

Вместе с тем анализ научно-педагогических источников показал, что система профессиональной подготовки специалистов по физическому воспитанию детей и молодежи в Австрии, которая имеет глубокие традиции и большую научно-практическую ценность, не была предметом специального исследования в Украине.

Цель статьи состоит в изучении предпосылок становления и истоков системы профессиональной подготовки специалистов по физическому воспитанию детей и молодежи в Австрии.

Результаты и обсуждение. История возникновения и развития идей физического воспитания детей и молодежи на территории Австрии насчитывает несколько веков, а подготовка учительских кадров к его осуществлению имеет давние традиции. Основы этого направления профессионального образования, по утверждениям ученых (R. Mülner, 2011; G. Stromaer, 1992), были заложены еще в эпоху Просвещения, и характеризовались постепенным появлением ряда важных политических, экономических, общественных предпосылок для становления первых форм организованного физического воспитания и профессиональной подготовки учителей к его реализации.

Среди культурно-исторических этапов развития европейской цивилизации Просвещение занимает особое место, ознаменовавшись возникновением и распространением широкого комплекса уникальных идей, настроений, достижений. Именно в эту эпоху произошла трансформация средневекового европейского общества в цивилизацию, которая постоянно динамично развивается. В этот исторический период над извечными ценностями традиционного общества возобладала идея неуклонного прогресса. Просвещение было явлением всеобъемлющим, и эта идея поступательного развития нашла проявление в различных сферах жизни и деятельности - политике, культуре, науке, образовании. Просвещение, как тип общественного сознания, строилось на материалистическом сенсуализме в теории познания, на признании 
силы человеческого разума, что нашло отражение в идеологии, мировоззрении, философских и социальных представлениях. Благодаря этому произошел переворот в мировоззрении людей - ум стал мерилом общественного прогресса. Поэтому вера во всесилие и всемогущество разума, культ знания, как инструменты проведения прогрессивных преобразований, являются важнейшими ценностями и ориентирами эпохи Просвещения (Вӧhm, 2013).

Учитывая это, эпоха Просвещения стала периодом важных научных открытий в области физики, математики, биологии, химии, медицины и т.д., которые разрушили прежнюю картину мира и способствовали созданию нового научного мировоззрения. Благодаря бурному развитию различных отраслей знания, достижением выдающихся ученых эпохи (Э. Дженнер, А. Лавуазье, К. Линней, Г. Лейбниц, И. Ньютон и др.) постепенно вытеснялись спиритические взгляды на сущность бытия, виталистические и теологические представления, устанавливались природные причинно-следственные связи и закономерности жизненных процессов, в результате чего на смену религиозному мировоззрению пришло рационалистическое.

В историко-культурном смысле Просвещение предстает и как синтез идей гуманизма. В центре внимания просветителей (Е. Jenner, А. Lavoisier, C. Linnaeus, G. Leibniz, I. Newton, etc.) находится человек во всем своеобразии его бытия и проявления. Даже само происхождение государства начинает трактоваться как общественный договор свободных людей, а цель его функционирования определяется как достижение общего блага с помощью эффективной политики власти в различных сферах жизнедеятельности. Широкую известность во времена Просвещения получила идея перестройки общественных отношений на основе рациональных подходов, справедливости, свободы, равенства и других гуманистических и демократических принципов, вытекающих из самой природы человечества, из неотъемлемых личностных прав каждого человека.

Просвещение было мощным идейным общеевропейским движением, в XVIII веке. Оно постепенно, несмотря на различия, масштабность или радикальность, охватило все страны континента. В частности, на территории Австрии просветительские идеи и идеалы оформились и реализовывались в рамках идеологии так называемого просветительского абсолютизма, то есть системы общественнополитических взглядов, направленных на модернизацию всех сфер жизни общества, устранение наиболее одиозных, устаревших явлений существующего строя, тормозящих движение вперед. Это была идеология реформ, осуществлявшихся с целью обновления институтов феодального общества, их адаптации к назревшим требованиям и потребностям. Реформы были направлены на развитие торговли и мануфактур, ликвидации сословных привилегий, преодоление феодальной разобщенности, освобождение крестьян от крепостной зависимости и тому подобное. Движущей силой реализации этой идеологии была сильная абсолютистская власть, способная обеспечить 
общественное благо на основе справедливого правления и действенного законодательства (Mitrofanow, 1910).

Преобразования в духе абсолютизма были на территории Австрии особенно масштабными и последовательными благодаря реформаторской деятельности императрицы Марии Терезии и ее преемника Иосифа II. Во время их правления было проведено большое количество реформ, определивших приоритеты развития монархии на десятилетия, а то и на века. Какую бы сферу жизни ни изучали исследователи новейшей истории Австрии - управление, финансовая и экономическая отрасль, военное дело, правосудие, здравоохранение, школьное образование и т.д. - они всегда приходят к выводу о том, что истоки еe становления достигают времен правления великой императрицы, утверждает историк А. Вандрушка (Wandruszka, 1989, 159-160).

Наиболее заметными результатами реформаторской деятельности Марии Терезии стали унификация системы судопроизводства, введение всеобщей воинской повинности и постоянной армии, отмена внутренних таможенных границ и сборов, создание управленческобюрократического аппарата, сужение влияния церкви на различные сферы жизни австрийского общества, ограничения произвола правящих слоев населения, расширение спектра прав и свобод для низших слоев общества и др. Многочисленные политико-административные, юридические, судебные, экономические, социальные реформы затрагивали интересы различных социальных слоев, способствовали развитию товарно-денежных отношений, расширяли и модернизировали традиционные связи в обществе, которые в течение предыдущих столетий обеспечивали его целостность и устойчивость. Они разрушали устои феодальной хозяйственной и политической системы, открывали возможности для развития и масштабных преобразований во многих областях человеческой деятельности (Wandruszka, 1989).

Начатые Марией Терезией преобразования были продолжены в реформах Иосифа II, приобретя более радикальный и практический характер. Своими политическими, экономическими, социальными преобразованиями он внес значительный вклад в модернизацию всей монархии. В частности, Иосиф II упорядочил систему административно-политического и финансового управления, сократив чиновничье-бюрократический аппарат, усовершенствовал сферу судопроизводства, четко определив поле деятельности судов различных инстанций, улучшил систему безопасности, сформировав государственную полицию, модернизировал церковную политику, ввел новые принципы общественного устройства, прежде всего ликвидировав крепостное право, как личную зависимость крестьян от господ и т.д. (Mitrofanow, 1910).

Итак, знаковыми достижениями эпохи Терезии и Иосифа в истории Австрии стали прежде всего стержневые внутренние реформы, направленные на решение злободневных проблем жизни различных слоев населения. Трансформации этого периода имели глубинный характер, ведь они подрывали основы государственно-политического 
строя, привычного уклада жизни и деятельности, имеющейся общественной структуры вопреки сопротивлению привилегированных слоев с целью обеспечения лучших условий жизнедеятельности для всех подданных монархии независимо от статуса, происхождения, материального положения. Убедительным доказательством такой направленности внутренней политики австрийских монархов этой исторической эпохи стали меры по обеспечению всенародного блага, среди которых, например, распространение образования среди народных масс, основания системы государственной медицинской помощи, создание системы государственной поддержки обездоленных слоев населения и др.

Усиление внимания к вопросам образования стало закономерным следствием положительных сдвигов в общественно-политической, экономической, общественно-культурной жизни Австрийской монархии во времена абсолютизма. Проблемы уровня образования населения, развития системы школьного образования, подготовки молодежи к трудовой деятельности в новых условиях развития товарно-денежных отношений, мануфактурного производства приобретали государственное значение (Zyolner, 2001). Процесс решения проблем был основан, прежде всего, на попытках ограничения влияния на образовательную деятельность, ликвидацию неграмотности широких народных масс и реформирование тогдашней системы образования. Неоспоримом заслугой императрицы в этом направлении является окончательное признание организации образовательной деятельности одной из главных обязанностей государства.

Образовательная реформа, осуществляемая во времена абсолютизма на территории Австрии, охватывала различные звенья тогдашней школьной системы. В частности, речь идет о направлениях развития как новых типов школ, так и совершенствовании, и адаптации к новым условиям старых. Следствием реформ стало усовершенствование университетского и гимназического образования, которые обеспечивали воспитание новых поколений общественной элиты; развитие реальных и промышленных школ, которые служили подготовкой молодежи к трудовой деятельности в новых условиях производства и хозяйствования. В то же время, если в сфере среднего и высшего образования трансформации направлены на совершенствование существующих образовательных традиций, то организация народного (начального, элементарного) образования являлась для власти совершенно новым делом, к выполнению которого были привлечены иностранные специалисты в этих вопросах, в частности прусский аббат и педагог, реформатор И. Фельбигер, который на основе собственной практической деятельности и опыте других государств, в деле народных школ издал специальный школьный устав для Габсбургской империи (Mitrofanov, 1907).

«Общим школьным порядком для нормальных, главных и общих школ во всех имперских наследственных землях» (1774) планировалось создание основы для народного школьного образования путем утверждения принципов функционирования системы школ, 
благоустройства школ, обоснование специфики их учебной деятельности и тому подобное. Обязательность школьного образования, разнотипность системы образования, светский характер обучения провозглашались основополагающими идеями развития системы школьного образования. Сеть народных школ структурировалась по трем типам (нормальные, главные, общие), вопросы целей и содержания их деятельности регулировались представленными в дополнениях учебными планами, где значительная часть религиозных предметов была заменена светскими практическими дисциплинами (Allgemeine Schulordnung, 1974).

«Общий школьный порядок» дал мощный стимул развитию системы народного образования на территории всей империи. Это был своего рода первый шаг на пути к общей государственной школе, которая давала доступ к знаниям представителям низших слоев общества, бедных слоев населения. Его положения предусматривали основания широкой сети элементарных школ для развития у детей и молодежи базовых умений и навыков чтения, письма, счета, знаниями по природоведению, религии, истории и традициях. Целью деятельности этих школ являлось воспитания молодых поколений подданных империи, своей выдержкой и трудолюбием, «честными помыслами и страхом Божиим» достойно служить государству и народу (Allgemeine Schulordnung, 1974).

Начатые Марией Терезией инициативы в сфере образования продолжил Иосиф II. Усилия монарха и правительства были направлены на решение текущих проблем системы школ, среди них:

образования;

определение общественной роли и функций системы детей и молодежи;

развитие государственной системы обучения и воспитания совершенствование структуры школьного управления; финансирование школьной системы; организация учебных заведений различных типов и уровней; создание специальных учреждений для подготовки учителей и т.д. (Mitrofanow, 1910).

Школьные реформы Иосифа II имели выраженное практическое направление, учитывая его понимание образования как инструмента достижения благосостояния народа и объединения широкого конгломерата этнически и культурно разнообразных сообществ в пределах мощного централизованного государства. Этой цели подчинены все структурные элементы системы образования - от университета до общей школы. Соответственно процесс реформирования имел комплексный характер, благодаря чему удалось достичь заметных изменений на всех звеньях образовательной системы. Прежде всего речь идет об организационной унификации образовательных учреждений, благоустройстве сети учебных заведений, преодоление повторений учебных программ на разных уровнях системы образования и т. 
В то же время, как и Мария Терезия, наибольшее внимание Иосиф II уделял вопросам развития именно народных школ и распространение элементарных знаний среди народных масс. Знания, науку и «добрый нрав» монарх провозгласил лучшими и правильными путями к общему благу всего народа и государства. Чтобы сделать начальное образование достоянием каждого подданного империи, число соответствующих школ увеличивалось в соответствии с количеством населения регионов империи, устанавливалась минимальная плата за обучение (1-2 крейцера в неделю), а при наличии специального документа о бедности (Armenzeugnis) и вовсе отменялась; предусматривались достаточно широкие свободы в сфере выбора языка обучения, религии и т.д. (Mitrofanow, 1910, 815).

Так, в эпоху Просвещения важное значение образования в жизни человека и общества стало для Габсбургской монархии общепризнанной аксиомой. Благодаря их последовательной образовательной политике в империи удалось сформировать одну из самых передовых систем обучения и воспитания в Европе того времени. Школьные реформы Марии Терезии и Иосифа II привели к поразительным изменениям прежде всего на ниве народного образования, обеспечив предпосылки для распространения грамотности среди широких слоев населения и воспитания представителей бедных слоев общества в качестве равноправных граждан и верных подданных империи.

Другой важной новацией этого периода австрийской истории стало основание государственной системы охраны здоровья населения. Именно в это время постепенно утверждаются новые подходы к медицине, как сфере научно-практической деятельности, профилактика болезней, сохранение и восстановление здоровья впервые начинают рассматриваться не как личное дело каждого человека, а как важное государственное дело и обязанность. Об этом свидетельствует, в частности, создание специальных государственных медико-санитарных инстанций, которые получили значительные административные и финансовые ресурсы для реализации политики государства в сфере охраны здоровья населения. Так, еще в 1753 году императрица Мария Терезия создала Санитарно-придворную депутацию, а также вывела изпод юрисдикции церковной власти Венский университет, подчинив при этом его медицинский факультет придворному врачу Г. ван Свитену, который почти полностью заменил имеющийся преподавательский состав своими единомышленниками (L. Auenbrurrer, A. Gaen, M. Shtiork, and others) готовыми к активному участию в решении общегосударственных проблем здравоохранения (Lesky, 1959).

Важная их заслуга заключается также в распространении представлений о реальных, объективных причин патологических процессов в человеческом организме и потере здоровья, преодолении средневековых стереотипов, что способствовало утверждению качественно новых подходов государственных деятелей и монархов к проблемам заболеваемости населения и основания государственных структур и инстанций, на которые возлагалась обязанность определения и 
внедрения в практику комплекса мер по сохранению и восстановлению здоровья жителей монархии. В частности, к задачам Санитарнопридворной депутации входили сбор сведений о санитарном состоянии всей территорий империи, осуществление санитарных и противоэпидемических мероприятий, разработка санитарного законодательства. Медицинский факультет, получив статус консультативного органа, отвечал за подбор врачей для проведения врачебно-санитарных мероприятий, научную обработку собранных данных, формирование научно обоснованных рекомендаций (Lesky, 1959).

Результатом совместной деятельности работников Санитарнопридворной депутации и профессоров медицинского факультета Венского университета стал утвержденый в 1770 году «Санитарный норматив» - первый специальный сборник медико-санитарных правил и установок, обязательных к исполнению на всей территории монархии. Документ содержал описание принципов организации системы здравоохранения на различных уровнях, устав профессиональной деятельности врача, нормы врачебной этики и тому подобное. Принятие этого врачебно-санитарного нормативного документа обеспечило поддержку органам государственной власти в практической реализации политики в сфере охраны здоровья населения и сыграло важную роль в окончательном утверждении государственной системы медикосанитарной помощи, так называемой «медицинской полиции», призванной сохранять, поддерживать, восстанавливать состояние здоровья жителей всех провинций империи (Handbuch der kaiserlichen, 1847).

Наибольший вклад в разработку концепции «медицинской полиции» сделал Й.П. Франк - австрийский врач, профессор Венского университета, основатель социальной гигиены как самостоятельной отрасли научных знаний. Свои соображения по организации медицинского дела на территории страны, вопросам охраны здоровья населения, санитарии и гигиены ученый системно изложил на страницах девятитомного труда «Система совершенной медицинской полиции». По замыслу Й.П. Франка «медицинская полиция», как отрасль государственной деятельности, должна отражать научно обоснованный и законодательно закреплённый комплекс мер по активному участию соответствующих государственных институтов в жизни человека с целью охраны и восстановления его здоровья в интересах общественной безопасности (Frank, 1780).

Предложенный Й.П. Франком комплекс медико-полицейских мер охватывал целый ряд задач и направлений деятельности: во-первых, обеспечение населения квалифицированными врачами с помощью кардинального реформирования системы их профессиональной подготовки; во-вторых, это интенсификация научно-исследовательской медицинской деятельности с целью выявления путей борьбы с болезнями; в-третьих, формирование государственной системы поддержки нуждающихся и социально незащищенных групп населения; в-четвертых, осуществление конкретных мероприятий, направленных 
на формирование здоровых условий жизни, питания и трудовой деятельности и т. д. Вся его деятельность направлена, таким образом, на обоснование проблем здоровья и благополучия населения, как одной из ключевых обязанностей государства и поиски эффективных подходов к их выполнению (Frank, 1780).

$\mathrm{B}$ поисках путей решения широкого спектра проблем охраны здоровья населения известные австрийские общественные деятели, врачи, ученые (Г. Венцель, Л. Гьолис, Р. Каштлер, Й.П. Франк, А. Фрёлиха и др.) особенно актуализировали вопрос высокой детской заболеваемости и смертности и возможностей их минимизации. В своих трудах они основательно раскрыли благоприятные и неблагоприятные факторы физического развития человека, особенности их влияния на этот процесс.

Авторы определили частые причины недостатков физического развития, потери здоровья и смертности детей, среди которых неправильный уход, жестокие физические наказания, плохие гигиенические условия жизни и роста детей, неудовлетворительное питание, устаревшие подходы к лечению распространенных детских болезней и т.п. (Wenzel, 1796; Gölis, 1811; Kastler, 1824; Frank, 1804; Fröhlich, 1802). Эти данные, по их утверждениям, являются результатом многочисленных наблюдений за жизнью детей, и причина этого, прежде всего, неосведомленность родителей и воспитателей с физиологией человеческого организма, закономерностями физического развития ребенка и способами его поддержки. В связи с этим австрийскими учеными были осуществлены многочисленные попытки опровержения распространенных стереотипов в уходе за детьми, освещение причин детской заболеваемости и смертности, разъяснения природных закономерностей развития ребенка, обоснование необходимых условий для его полноценного роста (Wenzel, 1796; Gölis,1811; Kastler, 1824; Frank, 1804; Fröhlich, 1802).

В своих трудах и докладах они начали разработку комплексного подхода к сохранению и поддержанию здоровья молодых поколений, включая различные нормативы и указания по уходу за детьми на основе анализа данных диетологии, гигиены, медицины и создавая, на соответствующих принципах, комплексные научные концепции профилактики пороков и патологий развития детей и молодежи. Исследователи дали важные рекомендации о заботе о ребенке, организации благоприятных условий его жизни и развития, правила поведения в угрожающих здоровью и жизни ребенка ситуациях, например, заболевания или последствия жестокого обращения.

Особое значение при этом отводилось вопросам полноценного развития физических сил и организма ребенка, мер и механизмов воздействия на беспрепятственный ход этого процесса. Важным средством физического развития и укрепления здоровья детей известные врачи и государственные деятели определили гимнастику и физические упражнения. В их трудах находим аргументированные представления о гимнастике, как лечебном и профилактическом средстве; подробные описания систем гимнастических упражнений, направленных на 
совершенствование функциональных возможностей человеческого организма в различные возрастные периоды, четкие методические рекомендации по особенностям их выполнения и т. Здесь авторы не ограничиваются презентацией физкультурных занятий для совершенствования функциональных возможностей человеческого организма, например бег, ходьба или плавание, но и представляют уникальный комплекс упражнений для развития сенсорных органов ребенка, его речевого аппарата, профилактики проблем здоровья и тому подобное. Подбор и рекомендации гимнастических упражнений авторы осуществляют в зависимости от их эффективности в совершенствовании всего разнообразия возможностей детей и предупреждении наиболее распространенных в то время проблем детского здоровья (Wenzel, 1796; Gölis,1811; Kastler, 1824; Frank, 1804; Fröhlich, 1802).

Обоснование гимнастики и физической культуры, как неотъемлемой составляющей системы школьного образования и необходимости специальной подготовки учителей к физическому воспитанию детей и молодежи на территории Австрии осуществлялось, кроме медицинских, и в пределах педагогических исследований. В частности, идея единства физического, интеллектуального и нравственно-духовного воспитания как методологического принципа школьного образования была представлена в работах педагога Ф.И. Кински. Свои размышления на эту тему он начинает с выяснения человеческой природы в целом и отмечает, что сущность человека - это совокупность всех его физических и душевных сил, находящихся в диалектической взаимозависимости и взаимообогащении. Учитывая это, физическая и духовная сущность являются двумя равноценными объектами, на которые должно быть направлено воспитание с целью достижения совершенства в обоих измерениях человеческого бытия.

В контексте единства и неразделимости физического и духовного развития человека, он считал физическое воспитание интегрированной составляющей образовательно-воспитательного процесса. Только во взаимосвязи физического, умственного, нравственного, трудового и т.д. воспитания возможно полноценное развертывание всех потенциальных сил и возможностей человеческого существа. Каждое направление воспитания, хотя и имеет свои цели и задачи, методы и средства, прямо или косвенно влияет на все аспекты развития человека (Supplementband zu den Schriften, 1892).

Так, физическое воспитание, предвидит, прежде всего, поддержание физического развития детей и молодежи, способствует формированию интеллектуальных и моральных качеств. Учитывая это, в физическом воспитании Ф.И. Кински видел основу формирования человека, а чередование физических упражнений с умственными занятиями считал наиболее рациональным способом взаимообогащения телесных и духовных сил человека. Свои педагогические соображения он воплощал непосредственно в практике учебного-воспитательного процесса в Терезианской военной академии в Винер-Нойштадте, которую возглавлял в течение 1779-1805 годов. 
Похожие рассуждения находим в работах другого австрийского педагога Ф.М. Фирталера. «Когда мы говорим о воспитании, мы думаем прежде всего о последовательном и систематическом руководстве процессом развития умственных способностей ребенка, то есть, о интеллектуальном воспитании. Однако, в этом контексте необходимо говорить и о физическом воспитании, то есть о поддержке физического развития ребенка, поскольку сущность личности кроется в единстве духа и тела», - отмечает педагог (Vierthaler, 1794 с. 17-18).

Учитывая это, цель образования, в частности школьного, по утверждениям педагога, должна заключаться не во выборочном культивировании отдельных способностей ребенка, а в поддержке его целостного, всестороннего развития. Тело человека, считает Ф.М. Фирталер, орган его души и разума, выполняет двойную функцию: с одной стороны, оно предоставляет материал для интеллектуальной деятельности, а с другой - обеспечивает проявление и реализацию результатов умственной активности - мыслей, идей и тому подобное. Поэтому сбалансированность различных направлений воспитания ребенка он определяет залогом полноценного раскрытия всех его сил и возможностей.

Сквозь призму этих соображений, он призвал к реформированию тогдашней школы и системы подготовки нового поколения учителей, которые смогут воспитывать не только «хороших читателей, писарей и счетоводов», а прежде всего физически здоровых и высоконравственных личностей. «Кто хочет воспитывать людей, тот должен хорошо знать и понимать человеческую природу и сущность во всей многогранности и единстве ее форм»- ключевое требование педагога к новому учителя (Vierthaler, 1794, 24-25).

Свои идеи он активно пропагандировал во время лекционных курсов в Зальцбургской учительской семинарии, руководителем которой был на протяжении 1790-1806 годов. Также Ф.М. Фирталер опубликовал ряд работ, в частности «Элементы методики и педагогики» (1791), «Очерки по школьной педагогики» (1794 г.), в которых изложил свои соображения по воспитанию молодого поколения, систематизировал достижения различных отраслей науки, в частности физиологии, психологии , философии и т.д., и обосновал их педагогическую ценность, охарактеризовал эффективные методики учебновоспитательной деятельности для вооружения будущих учителей глубокими базовыми знаниями и организационно-методическими умениями, необходимыми для успешной педагогической деятельности.

Конкретным предлогом для развития теории физического воспитания, по мнению Г. Штромаера, была потребность в научной подготовке учительских кадров. Соответствующие теоретические положения относительно физического развития и воспитания детей и молодежи служили содержательной основой лекционных курсов (Strohmeyer, 1992, 318). На территории Австрии впервые такие курсы были организованы при школе в Св. Анны в Вене, которая обеспечивала подготовку учительских кадров для народных школ. В частности в течение 1789-1838 годов здесь трижды в неделю проводились лекции по 
вопросам физического воспитания для будущих учителей всех направлений подготовки, во время которых освещались преимущественно физиологические и гигиенические аспекты физического развития, а также рассматривались цели и технологии проведения гимнастических упражнений с детьми.

Лекционные курсы по проблемам физического воспитания читали преимущественно специалисты медицинского профиля, в частности в упомянутой вышей школе эту задачу выполнял профессор Венского университета Л. Новаг (Nowag, 1842), автор фундаментального труда «О физическом воспитании человека» (1820-1823 гг.), переизданного впоследствии под названием «Основы физического воспитания человека» (1843 г.). Так, содержание «науки о физическом воспитании», a, соответственно, и свою работу ученый структурировал в три части: «физиология человеческого организма», «диететика» и «гимнастика», что свидетельствует о попытках применения комплексного подхода к решению проблем полноценного физического развития детей и молодежи через просвещение в этих вопросах родителей, воспитателей, учителей, которым, собственно, и адресовалась эта книга.

Тематика труда является богатой и разнообразной, включая подробную характеристику строения организма человека, анализ его функциональных возможностей, базовых особенностей развития в разные возрастные периоды, обоснование влияния внешних условий и факторов на развитие физических сил и тому подобное. Особое внимание в этом контексте ученый уделяет вопросу роли воспитания на процесс развития человека, определению его сущности, целей, задач: «Телесное (физическое) воспитание человека имеет своей целью развитие и совершенствование способностей и сил человеческого организма; на момент рождения эти силы находятся в несовершенной, скрытой форме и разворачиваются только с течением времени; об их пробуждении заботится прежде всего природа, однако их развертывание часто осложняется неблагоприятными условиями и факторами. Устранять преграды, стоящие на пути развития физических задатков, способствовать гармоничному развитию физических, умственных и духовных сил с учетом их взаимозависимости и взаимосвязи - это и есть задание физического или телесного воспитания» (Nowag, 1842, 11 12).

Л. Новаг определил, что достижению соответствующих целей способствуют основательные знания родителей, воспитателей, учителей о физиологических, биологических закономерностях развития детей, медико-гигиенических нормах условий их жизнедеятельности, педагогических средствах их поддержки на пути естественного развития их физических сил. Работа ученого легла в основу содержания его лекций по физическому воспитанию детей и молодежи для будущих учителей и построена на междисциплинарном подходе к обозначенной педагогической проблеме. Различные аспекты процесса физического воспитания ученый излагает из различных научных перспектив медицинской, биологической, педагогической, что позволяло слушателям соответствующего лекционного курса комплексно 
осмыслить их сущность, сформировать разностороннее видение проблемы или задачи и выбрать оптимальный подход к ее решению.

Надлежащий научный уровень подготовки учителей к спортивновоспитательной деятельности с детьми на территории Австрии обеспечивался и благодаря усилиям первого австрийского профессора педагогики В.Е. Мильда. Он сделал весомый вклад в теоретическую разработку идей и принципов физического воспитания подрастающего поколения и их популяризацию во время лекционных курсов по педагогике среди студентов Венского университета. Непосредственным результатом его научно-педагогической деятельности стал фундаментальный труд «Учебник по общей педагогике» (1811-1813 гг.), который к середине XIX века был официально утвержденным учебным изданием с систематизированным изложением педагогики как науки для всех педагогических учебных заведений Австрии. Первый том труда охватывает широкий круг вопросов в сфере физического и умственного воспитания, второй - посвящен рассмотрению особенностей эстетического и нравственного воспитания. Цель своей научной деятельности ученый видел не в создании чего-то совершенно нового, а в систематизации всех имеющихся достижений науки и практики и обосновании их значение для разработки современной образовательной теории и организации учебно-воспитательного процесса.

В своем труде педагог обосновывает тесную взаимосвязь умственного и физического развития, указывает на распространенные опасности, вызванные его пренебрежением в процессе образовательной деятельности, и убедительно аргументирует пользу целенаправленного, организованного физического воспитания детей и молодежи (Milde, 1811 - 1813). Ключевые идеи автора по воспитанию детей и молодежи можем представить в ряде тезисов:

исходная основа воспитания - это глубокое знание человеческой сущности и природы.

$\square$ индивидуальность ребенка - основа всего образовательного процесса.

цель воспитания - всестороннее развитие личности каждого ученика.

ум и сердце, тело и душа ребенка - абсолютно равнозначны объекты воспитания.

$\square$ воспитание - это побуждение, направление и подготовка к непрерывному самосовершенствованию (Milde, 1811 - 1813).

В.Е. Мильд уделял пристальное внимание не только вопросам нравственного и интеллектуального воспитания школьников, но и проблеме их физического роста и воспитания. В разделе о физических задатках человека и их развитии, ученый продемонстрировал глубокие знания новейших медицинских, гигиенических, валеологических достижений в сфере человеческого онтогенеза, охраны здоровья детей и молодежи и поддержки их физического развития, которые, в свою очередь, считал необходимой предпосылкой воспитательной деятельности. Возможности и одновременно пределы физического 
воспитания, подытожил исследователь в результате научных поисков, кроются прежде всего в естественных задатках ребенка, которые являются движущей силой воспитательного процесса, а следовательно сущность физического воспитания заключается в поддержке ребенка на пути естественного развития (Milde, 1811 - 1813).

Благодаря преподавательской деятельности В.Е. Мильда в Венском университете вопросы физического воспитания школьников стали обязательным элементом содержания лекционных курсов по педагогике, целью которых было обеспечение будущих учителей систематизированным материалом для размышлений и осознания проблемы образования и воспитания молодого поколения. Заслугу В.Е. Мильда австрийские исследователи (R. Mülner, G. Shtromaer and others) видят, прежде всего, в закладке научной базы для становления организованной системы школьного физического воспитания в Австрии. В то же время, непосредственный толчок ее становления и развития, по их мнению, дали революционные события 1848-1849 годов, направленные на ослабление противоречий в различных сферах жизнедеятельности общества в целом и открытие новых перспектив в области образования молодого поколения в частности (Müllner, 2011; Strohmeyer, 1992).

В совершенствовании системы физического воспитания, речь идет о ключевых достижениях, и прежде всего, это включение физической культуры как учебного предмета в образовательные программы австрийских школ. Стоит отметить, что ход этого процесса на территории Австрии был довольно неравномерным и длительным: в 1848-1849 годах физическая культура была включена как факультативная дисциплина в программу реальных школ, гимназий и высших школ, в 1869 году она стала неотъемлемой составляющей образовательной программы народных школ, на нее освоение отводилась 1 - 2 часа в неделю.

Наличие физической культуры в учебных планах и программах австрийских образовательных учреждений обусловило потребность в педагогических кадрах соответствующего профиля, для решения которой правительство страны прилагало немало усилий. Так, в 1848 году при Венском университете был учрежден специальный институт физической культуры (Universitätsturnanstalt), который возглавил Р. Штефани - один из первопроходцев в сфере организации системы школьного физического воспитания детей на территории Германии, Чехии, Австрии, преподаватель гимнастики Терезианской академии. Спектр функций и задач нового учебного заведения был достаточно разнообразным:

образование специалистов по физической культуре и воспитанию молодежи для всех вузов Вены (Венский университет, Политехнический институт, Академия изобразительного искусства);

подготовка учительских кадров к осуществлению организованного физического воспитания учащихся гимназий и реальных школ; 
контроль качества физического воспитания детей и молодежи в образовательных учреждениях различных уровней, развитие теории физического воспитания;

консультационная помощь государственным структурам по вопросам организации и развития физического воспитания молодого поколения на региональном и общегосударственном уровне (Strohmeyer, 1971).

Основания отдельного института физической культуры с названными направлениями деятельности стало исходным моментом начала государственной системы подготовки кадрового обеспечения сферы физического воспитания детей и молодежи в Австрии. Дальнейшие шаги правительства страны направлялись прежде всего на создание нормативно-правовой базы профессиональной подготовки специалистов по физическому воспитанию. В частности, в 1870 году Министерство образования и культуры издало постановление об аттестации учителей физической культуры. Целью этой процедуры была проверка профессиональной компетентности будущих специалистов по физическому воспитанию, в частности уровня их общеобразовательной подготовки, знаний в области анатомии и физиологии человеческого организма, осведомленности с общими основами физической культуры, то есть историей ее развития, ее целью и задачами в системе образования, методами , средствами, способами организации физического воспитания и т.д. (Verordnung des Ministers, 1870).

Главной предпосылкой допуска к аттестации было завершение обучения в институте физической культуры, общая продолжительность которого составляла 4 семестра. Программа подготовки предусматривала прежде всего активные практические тренировки и упражнения будущих учителей физической культуры в различных видах спорта с одновременным объяснением техники их выполнения, а также теоретическую подготовку в области истории физической культуры, ее общенаучных основ и технологических аспектов. Неотъемлемой составляющей программы подготовки будущих учителей физической культуры была также методика ее преподавания и педагогическая практика в образовательных учреждениях. Впоследствии, учитывая необходимость увеличения объемов подготовки специалистов физического воспитания и одновременно ограниченность ресурсов и возможностей института физической культуры, аналогичные курсы были также предложены на философском факультете Инсбрукского и Грацкого университетов (Groll, 1962; Müllner, 2011; Strohmeyer, 1971).

\section{Выводы}

Совершенный анализ дает основания констатировать, что физическое воспитание детей и молодежи в Австрии и подготовка учительских кадров к его осуществлению имеет давние традиции. Их исторические истоки прослеживаются еще со времен Просвещения, когда сформировался комплекс специфических предпосылок для масштабной реализации социально-педагогических мероприятий по укреплению 
здоровья детей и их гармоничного физического развития. Спектр этих предпосылок является достаточно широким, от политикоэкономических реалий тогдашней жизни монархии (индустриализация, технологизация, урбанизация, демократизация жизнедеятельности общества и, как следствие, изменение жизненных стандартов населения) к новым медико-биологическим, социально-гигиеническим, антрополого педагогическим и т.д. тенденциям (усиление внимания к проблемам охраны здоровья населения, распространение образования среди широких народных масс и т. д.).

Вопросы профессиональной подготовки учителей физической культуры стали объектом внимания австрийских ученых еще в XVIII веке и рассматривались прежде всего в контексте целей и задач физического воспитания детей и молодежи. Определяя ценность и сущность физического воспитания, его функции в системе школьного образования, исследователи (Ф.И. Кински, В.Е. Мильда, Л. Новаг, Ф. Фирталер, Й.П. Франк и др.) указывали на необходимость надлежащей подготовки учительских кадров этого профиля, которая основывалась на новейших достижениях различных отраслей науки (анатомии, физиологии, медицины, гигиены, психологии, педагогики и т.д.) и интенсивной методико-технологической и практической подготовке в различных видах спортивной и физкультурной деятельности.

Рассматривая задачи школьного физического воспитания, педагоги определили широкий спектр требований к учителю физической культуры (знание и понимание человеческой природы и законов человеческого онтогенеза, работа с современными задачами, принципами, методами школьного образования, понимание сущности и целей физического воспитания в системе школьного образования, осознание функций и технологий выполнения физических упражнений и т.д.) и определили условия их реализации (создание институциональной сети профессиональной подготовки специалистов по физическому воспитанию, усиление ее научного характера, тесная связь теории и практики обучения, соответствие потребностям и задачам практической профессиональной деятельности и т. д.). Исходя из практических потребностей школьного физического воспитания были заложены основы системы профессиональной подготовки специалистов физического воспитания, в форме двухлетних курсов.

\section{Bibliographic references}

MITROFANOV, P. P. 1907. The political activity of Joseph II, her supporters and her enemies. SPb. : Typography of I. N. Skorokhodov. 782 p.

JOHANN THOMAS EHLEN VON TRATTNER, 1974. Allgemeine Schulordnung für die deutschen Normal-, Haupt- und Trivialschulen in samtlichen Kaiserlich-Koniglichen Erblandern, Wien, 60 p.

BOHM, W. 2013. Geschichte der Padagogik. Von Platon bis zur Gegenwart. München, C.H.Beck. 127 p.

FRANK, J. P. 1780. System einer vollstandigen medicinischen Polizey. Wien, Johann Thomas Edler von Trattnern. - Bd. 1. 634 p. 
FRANK J. P. 1804. System einer vollstandigen medicinischen Polizey. Mannheim, C. F. Schwan, 1804. Bd. 2. 664 p.

FROHLICH, A. 1802. Lehre uber die erste Grundlage des menschlichen Glucks durch physische Erziehung. Wien, Pichler. p. 195.

GOLIS, L.A. 1811. Vorschlage zur Verbesserung der korperlichen Kindererziehung in den ersten Lebensperioden. Wien, A. Strauß. 170 p.

GROLL, H. 1962. Vom „Turnlehrerausbildungskurs“ zum „Institut fur Leibeserziehung der Universitat". H. Groll. Idee und Gestalt der Leibeserziehung von heute (Gesammelte Aufsatze). II. Band. Wien, Osterreichischer Bundesverlag. pp.139-145.

Handbuch der kaiserlichen-koniglichen Sanitat-Gesetze und Verordnungen mit besonderer Beziehung auf innerosterreichische Provinzen Hrsg. M. Macher. - Graz, J. F. Dirnbock, 1847. 587 p.

HEINTEL G. 2000. Uberlegungen zur Lehrerinnenausbildung an der Universitat. Schulheft. Nr. 97. pp. 154-161.

KASTLER, R.M. 1824. Praktische Abhandlungen und Gedanken zur heutigen physischen Erziehung der Kinder. Wien, Tendler u. v. Manstein. p. 110 .

KLEINER K. 2001. Selbstreflexion statt Selbstfokussierung: Was soll die Reform des Lehramtsstudiums «Bewegung und Sport» fur die Lehrerinnenbildung leisten? Spectrum der Sportwissenschaften. Nr. 13(2). pp. 57-71.

LESKY, E. 1959. Osterreichisches Gesundheitswesen im Zeitalter des aufgeklarten Absolutismus. Wien, VOAW. 228 p.

MITROFANOW, P. 1910. Joseph II. Seine politische und kulturelle Tatigkeit. Wien, C.W.Stern. 870 p.

MULLNER, R. 2011. Perspektiven der historischen Sport- und Bewegungskulturforschung. Wien, Lit Verlag. 380 p.

NOWAG, L. 1842. Grundsatze der physischen Erziehung des Menschen. Wien, Wallishausser. $274 \mathrm{p}$.

STROHMEIER, H. 1971. Das Institut fur Leibeserziehung 1871-1971 / H. Strohmeyer // Leibesubungen und Leibeserziehung. - Nr. 25. pp. 12-27.

STROHMEYER, H. 1992. Die Geschichte der Erforschung des Phanomens «Leibeserziehung». Zur Geschichte des osterreichischen Bildungswesens. Probleme und Perspektive der Forschung. Wien, Verlag der Osterreichischen Akademie der Forschung - H. 25. pp. 315-338.

SEIDEL L. W. \& Sohn, 1892. Supplementband zu den Schriften des Grafen Franz Kinsky / W. Eymer (Hrsg). Wien, 122 p.

VERORDNUNG DES MINISTERS FUR KULTUS und Unterricht vom 10. September 1870, betreffend eine Prufungsordnung und eine PrufungsKommission fur Lehramtskandidaten des Turnens. Verordnungsblatt fur den Dienstbereich des Ministeriums fur Kultus und Unterricht. Wien, Verlag des Ministeriums fur Kultus und Unterricht, 1870. pp. 557-560.

VIERTHALER, F. M. 1794. Entwurf der Schulerziehungskunde. Salzburg, Mayr. $109 \mathrm{p}$.

WANDRUSZKA, A. 1989. Das Haus Habsburg. Die Geschichte einer Europaischen Dynastie. Wien-Freiburg-Basel : Herder \& Co. 224 p. 
WENZEL, G.I. 1796. Drei Bucher von den Pflichten der Mutter. Wien, Rotzl u. Kaulfuss. 184 p.

ZYOLNER, E. 2001. History of Austria: Trans. s nim. Lviv: Litopis. 712 p.

Olha Romanchuk

Drohobych State Pedagogical University named after Ivan Franko,

st. I. Franko, 24

82100, Drohobych

Ukraine

olgabrvska@gmail.com 